\title{
Influence of Intensity and Duration of Regulated Deficit Irrigation on Erythroneura elegantula (Hemiptera: Cicadellidae) on Grape
}

\author{
MICHAEL J. COSTELLO ${ }^{1}$ AND SHAWN T. VEYSEY
}

Horticulture and Crop Science Department, Cal Poly State University, San Luis Obispo, CA 93407

\begin{abstract}
J. Econ. Entomol. 105(4): 1293-1301 (2012); DOI: http://dx.doi.org/10.1603/EC11321
ABSTRACT We conducted studies in a Paso Robles, CA, grape (Vitis vinifera L.) vineyard in 2002 and 2003 to estimate the impact of regulated deficit irrigation (RDI) intensity and duration on western grape leafhopper, Erythroneura elegantula Osborn. Treatments were based on deficit intensity, 50 and $25 \%$ of standard irrigation (moderate and severe deficits, respectively), and deficit duration, 3 or $6 \mathrm{wk}$ time, initiated at the grape phenological stage of berry set. The standard irrigation served as the control, and was intended to be as close to $100 \%$ of evapotranspiration (1.0 ETc) for grape in this area. Each week we took counts of leafhopper nymphs and estimated stomatal conductance, and at the end of each leafhopper generation we counted live, hatched and parasitized leafhopper eggs. Second generation leafhopper nymphal density was lowered by about 38 and $70 \%$ in 2002 and 2003, respectively, but in 2003 only the severe deficit had a negative effect on the third generation. This same pattern was seen in oviposition: second generation egg density was reduced by about $44 \%$ in the deficit treatments, but in the third generation only the severe deficit was lower than the control. There was little difference between the 3 vs. 6 wk duration in nymphal or egg density. The differences among treatments in second generation peak nymphal density were greater than the differences in second generation hatched eggs, suggesting that in addition to egg mortality, the deficits also affected nymphal mortality. Management strategies for maintaining leafhopper density low in the second generation and third generations include maintaining a sub-1.0 ETc irrigation strategy after the main RDI period, or reinstating the RDI to correspond to the third generation.
\end{abstract}

KEY WORDS leafhopper, vineyard, water, regulated deficit irrigation (RDI)

Erythroneura spp. leafhoppers (Hemiptera: Cicadellidae: Typhlocybinae) are an economic concern for commercial grape, Vitis vinifera L., growers in many viticultural regions of the United States, including California, Arizona, Oregon, Washington, and upstate New York. In California, western grape leafhopper, Erythroneura elegantula Osborn, is found throughout the state, whereas Erythroneura variabilis Beamer is restricted to southern California, parts of the San Joaquin Valley, and warmer regions of the North Coast. Erythroneura spp. overwinter as reproductively diapausing adults, and females oviposit on newly produced grape tissue in the spring. In the Paso Robles region on the Central Coast, first generation nymphs eclose in early to mid-June. In this region, at least two generations, and sometimes a third, occur annually. Treatment thresholds for wine grapes on the Central Coast vary considerably, but they are typically in the range of an average of 4-10 nymphs per leaf. During the time of this study, Erythroneura spp. were treated for chemically on $\approx 93,000$ ha of vineyards (California Department of Pesticide Regulation 2004).

\footnotetext{
${ }^{1}$ Corresponding author, e-mail: mcostell@calpoly.edu.
}

$V$. vinifera is the only commercial host plant for Erythroneura spp. in California. Eggs are laid under the leaf cuticle, and nymphs and adults feed on cells in the mesophyll region, causing loss of chlorophyll and potentially a reduction in the rate of photosynthesis. In California coastal regions, Erythroneura spp. have two to three generations per season, depending on the climate and the weather in any given year.

Several cicadellids, including the Erythroneura spp., have been shown to be sensitive to host plant water stress, regardless of the type of plant tissue fed upon. Potato leafhopper, Empoasca fabae (Harris), feeds on phloem as well as mesophyll cells (Hunter and Backus 1989) and has been shown to have reduced performance on water-stressed alfalfa, Medicago sativa $\mathrm{L}$. (Schroeder et al. 1988, Hoffman and Hogg 1992). Fornasiero et al. (2012) found lower densities of Empoasca vitis (Göthe) on nonirrigated versus irrigated grape in Italy. Glassy-winged sharpshooter, Homalodisca vitripennis (Germar), feeds on xylem and was found to have lower densities on field citrus (Citrus spp.) irrigated at $60 \%$ of estimated crop evapotranspiration $\left(0.60 \mathrm{ET}_{\mathrm{c}}\right)$ versus $0.8 \mathrm{ET}_{\mathrm{c}}$ or $1.0 \mathrm{ET}_{\mathrm{c}}$ (Krugner et al. 2009), and it was less abundant and had decreased feeding rates on drought-stressed citrus in the 
Table 1. Summary of estimated $E T_{c}$ and amount of water applied for each deficit period and for the season

\begin{tabular}{lcccccc}
\hline \hline & \multicolumn{5}{c}{ Treatment } \\
\cline { 2 - 6 } & $\begin{array}{c}\text { Standard irrigation } \\
(\text { control })\end{array}$ & $\begin{array}{c}\text { Moderate }(50 \% \\
\text { irrigation) } 3 \mathrm{wk}\end{array}$ & $\begin{array}{c}\text { Severe }(25 \% \\
\text { irrigation) } 3 \mathrm{wk}\end{array}$ & $\begin{array}{c}\text { Moderate }(50 \% \\
\text { irrigation) } 6 \mathrm{wk}\end{array}$ & $\begin{array}{c}\text { Severe }(25 \% \\
\text { irrigation) } 6 \text { wk }\end{array}$ & Estimated ET $_{\mathrm{c}}$ \\
\hline 2002 & $314\left(0.92 \mathrm{ET}_{\mathrm{c}}\right)$ & 262 & 234 & 231 & 191 & 340 \\
2003 & $305\left(0.94 \mathrm{ET}_{\mathrm{c}}\right)$ & 268 & 244 & 239 & 214 & 325 \\
\hline
\end{tabular}

Standard irrigation period is 30 April 30-1 October.

laboratory (Nadel et al. 2008). Trichilo et al. (1990) and Daane and Williams (2003) found Erythroneura spp. to have lower densities on vines watered at an irrigation level of $<1.0 \mathrm{ET}_{\mathrm{c}}$ over the course of the grape growing season.

Regulated deficit irrigation (RDI) (Chalmers et al. 1986) is a management technique designed to reduce the amount of applied water relative to $1.0 \mathrm{ET}_{\mathrm{c}}$ during key periods in the growing season of a perennial crop. On wine grapes, RDI is typically initiated near berry set (Prichard et al. 2004). The objectives of RDI include improvements in the ratio between shoot growth and fruit load, and fruit and wine quality (Chaves et al. 2007), and results have had varied effects on grape vigor and yield. Recent RDI research efforts have continued in a variety of viticultural regions worldwide, including Portugal (dos Santos et al. 2007), Spain (Santesteban et al. 2011), Brazil (Dantas et al. 2007), and Chile (Acevedo-Opazo et al. 2010).

Costello (2008) imposed RDIs of at least $50 \%$ of full irrigation (i.e., near 1.0 $\mathrm{ET}_{\mathrm{c}}$ ) for a 6 -wk period from grape berry set to veraison (initiation of berry ripening), finding second generation Erythroneura spp. nymphal density lower by $\approx 40 \%$ at one field site and $51 \%$ at another, and egg density by $\approx 30 \%$ and $54 \%$ at the same sites, respectively. However, in $1 \mathrm{yr}$ comparing 50 to $25 \%$ irrigation treatments, there was no significant difference in nymphal or egg density. Costello (2008) did not vary the duration of the deficit treatments, nor did he look at the impact of the deficits on the third generation of leafhopper nymphs.

The purpose of this study was to look not only at RDI intensity but also at duration of deficit, comparing a short time period of $3 \mathrm{wk}$ with the longer period of $6 \mathrm{wk}$, on the density of second as well as third generation nymphs and eggs of E. elegantula. Crop yield and quality results are presented in another paper (Costello and Patterson 2012).

\section{Materials and Methods}

We conducted experiments in 2002 and 2003 at Steinbeck Vineyards, located $\approx 15 \mathrm{~km}$ east of Paso Robles, in San Luis Obispo County, CA, in a vineyard for commercial wine grape production. The study vineyard was established in 1992, with 'Cabernet Sauvignon,' clone 8 on $5 \mathrm{C}$ rootstock. Rows were spaced $3.3 \mathrm{~m}$ wide and vines spaced $2.1 \mathrm{~m}$ within the row. Vines were trained to quadrilateral cordons and spur pruned. Soil type at the sites was a San Ysidro loam with a clay-to-clay loam subsoil at $58-96 \mathrm{~cm}$. In 2002, the study site was located on the southwestern corner of the vineyard, but because we observed a high soil water buffering capacity in one block, in 2003 we moved the site to the northwestern corner, to achieve better soil uniformity.

The design for the experiments was a randomized complete block, split plot, with the main plot factor intensity of deficit irrigation and the subplot factor duration of the deficit. The three levels of the deficit intensity factor were 1) $50 \%$ of standard irrigation (moderate deficit), 2) $25 \%$ of standard irrigation (severe deficit), and 3) standard irrigation (the control). The two levels of deficit duration were 1) $3 \mathrm{wk}$ after deficit initiation and 2) $6 \mathrm{wk}$ after deficit initiation. We replicated the treatments three times. Plot size was 16.5 by $14.7 \mathrm{~m}$ (six rows by eight vines). Moderate and severe deficit treatment plots were divided into two (i.e., the split plots) for the duration treatments (3 versus 6 wk). Subplots were separated by one vine row, and two vines on either end of the subplot as buffers.

The control or standard irrigation treatment for intensity was based on the grower's normal practice at the vineyard, i.e., to irrigate close to $1.0 \mathrm{ET}_{\mathrm{c}}$ throughout the season: $\mathrm{ET}_{\mathrm{c}}=\mathrm{k}_{\mathrm{c}} \times \mathrm{ET}_{\mathrm{o}}$, where $\mathrm{k}_{\mathrm{c}}$ is the crop coefficient and $\mathrm{ET}_{\mathrm{o}}$ is the estimated water use of a clipped grass crop. To estimate how accurate the practice was, we used the $\mathrm{k}_{\mathrm{c}}$ values published by Williams et al. (2003) and $\mathrm{ET}_{\mathrm{o}}$ values from the Paso Robles Vintners and Growers Association weather station in Paso Robles, and we compared the values to the three treatments. The estimated $\mathrm{ET}_{\mathrm{c}}$ and amount of water applied for each deficit period and for the season are summarized in Table 1 . We regulated irrigations using in-line programmed controllers (Gilmour, Somerset, PA), and the amount of water applied was estimated by placing a drip emitter into an 80-liter collection container in each subplot; we monitored the subplots weekly. Before the imposition of the RDI treatments, vines were watered according to the standard irrigation. In 2002 , deficit treatments began on 21 June, the duration split began on 15 July, and deficits ceased on 6 August. In 2003, deficits began on 21 June, the duration split began on 14 July, and deficits ceased on 10 August.

Pesticides applied during the study consisted of elemental sulfur and demethylation inhibitor fungicides for powdery mildew (Erysiphe necator Schwein) and glyphosate for weed management. None of these pesticides is known to have a significant effect on leafhopper mortality.

We estimated vine water stress by measuring stomatal conductance $\left(\right.$ moles $\left.\mathrm{CO}_{2} / \mathrm{m}^{2} / \mathrm{s}\right)$ with an LI- 


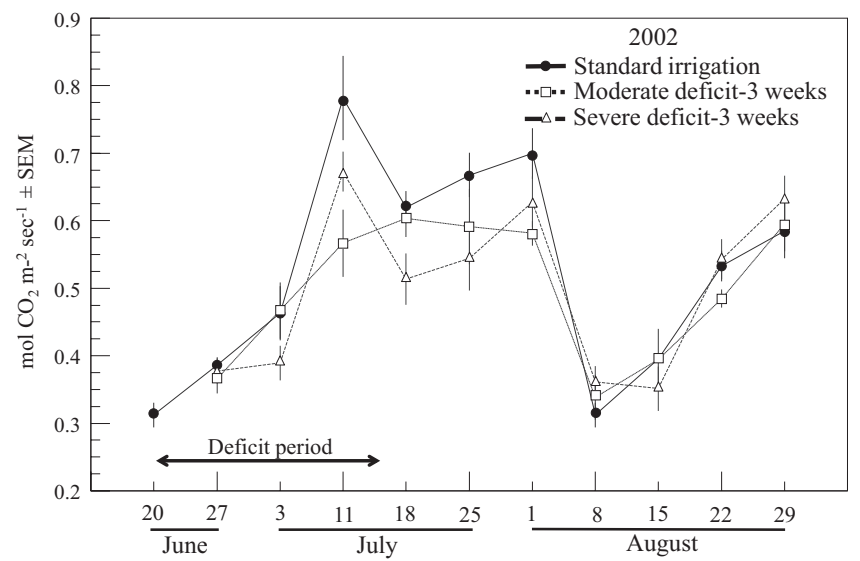

Fig. 1. Stomatal conductance (mean $\mathrm{mol} \mathrm{CO}_{2} \mathrm{~m}^{-2} \mathrm{~s}^{-1} \pm \mathrm{SE}$ ) over time, 2002, 3-wk deficit duration.

6200 portable photosynthesis system (LI-COR Biosciences, Lincoln, NE), taking five readings per plot per week between 1100 and 1400 hours, between 20 June and 29 August in 2002, and between 25 June and 3 September in 2003. We took weekly counts of leafhopper nymphs from 20 June to 19 September (first and second generations) in 2002 and from 25 June to 15 October (first, second, and third generations) in 2003, sampling 20 leaves per plot until the irrigation duration split, and thereafter on 15 leaves per plot. We did not sample leafhopper adults. We counted leafhopper eggs after the end of the first, second, and third generations, sampling 20 mature leaves per subplot. We brought the leaves back to the laboratory, cut them in half, and counted eggs on the half-leaves under a $40 \times$ dissecting microscope, and doubled that number to get an estimate of eggs per leaf. Eggs were scored as hatched, live or parasitized by the egg parasitoids Anagrus spp. In 2002, very few eggs were recorded, and the data are not included here.

Stomatal conductance and nymphal density data were $\log _{10}$ transformed, and we analyzed data by repeated measures analysis of variance (ANOVA), with mean separation by orthogonal contrasts (SAS Institute 2010). Contrasts compared the combined deficit treatments to the control, the intensity (moderate versus severe) deficits, or the duration ( 3 versus $6 \mathrm{wk}$ ) deficits. Leafhopper egg density was analyzed by ANOVA, with mean separation using Tukey's honestly significant difference. We considered differences statistically significant at $P<0.05$.

\section{Results}

Applied Water. Water applied in each year and a comparison with estimated $\mathrm{ET}_{\mathrm{c}}$ is shown in Table 1. The control treatment was $92.16 \%$ of estimated $\mathrm{ET}_{\mathrm{c}}$ in 2002 and $93.75 \%$ in 2003. The greatest difference among deficit treatments was between the severe deficit at 6 -wk duration, which was $26.9 \%$ lower than the moderate deficit at 6-wk duration in 2002 and 20.3\% lower in 2003 (Table 1). The treatments that differed the least were the moderate deficit at 6 -wk duration, which was just $1.4 \%$ lower than the severe deficit at three weeks duration in 2002 and 2.0\% lower in 2003 (Table 1).

Stomatal Conductance. Results of stomatal conductance indicate an effect of RDI in each year, but there was not a consistent correspondence between stomatal conductance and the deficit irrigation period. In 2002 (Figs. 1 and 2), there was no significant effect for the first two postdeficit samplings, but the following week (11 July) the deficit treatments showed a $21.0 \%$ reduction in stomatal conductance from the control (contrast: $F=8.29$; df $=1,22 ; P<0.01$ ), and the moderate deficit treatment was lower than the severe deficit by $20.4 \%$ (contrast: $F=5.47 ; \mathrm{df}=1,22 ; P=$ $0.02)$. There was an overall effect for the three weeks (18 July-1 August) after the cessation of the 3-wk deficit (repeated measures ANOVA: $F=14.78 ; \mathrm{df}=2$, 49; $P<0.01$ ), with the deficit treatments $18 \%$ lower than the control (contrast: $F=28.21$; df $=1,49 ; P<$ 0.01 ), but no difference between moderate and severe deficits (contrast: $F=1.35 ; \mathrm{df}=1,49 ; P=0.25$ ). There was also a deficit duration effect, with the 6 -wk time $7.6 \%$ lower than the 3 -wk time $(F=6.57 ; \mathrm{df}=1,42$; $P=0.01)$, but no interaction between intensity and duration $(F=1.64 ; \mathrm{df}=2,42 ; P=0.20)$. For the postdeficit period of 8-29 August, there was no overall effect of intensity $(F=2.06 ; \mathrm{df}=2,49 ; P=0.13)$, but there was an effect of duration $(F=37.44 ; \mathrm{df}=1,28$; $P<0.01)$, with deficit effect at $6 \mathrm{wk} 15.8 \%$ lower than that at $3 \mathrm{wk}$.

In 2003, there was a significant difference among treatments for the first $3 \mathrm{wk}$ (25 June-14 July) (repeated measures ANOVA: $F=9.16$; $\mathrm{df}=2,22 ; P<$ 0.01 ) (Figs. 3 and 4), with the contrast between the control and the deficits significant $(F=17.70 ; \mathrm{df}=1$, 22; $P<0.01$ ), and the deficit treatments lowered by $26.1 \%$ compared with control, but no difference between the moderate and severe deficit treatments $(F=0.62 ; \mathrm{df}=1,22 ; P=0.44)$. For the subsequent 3 wk (23 July-6 August), there was a significant effect of deficit intensity for the 3-wk duration $(F=6.23$; $\mathrm{df}=2,22 ; P<0.01)$, with the deficits $10.3 \%$ lower than the control (contrast: $F=11.39$; $\mathrm{df}=1,22 ; P<0.01$ ), 


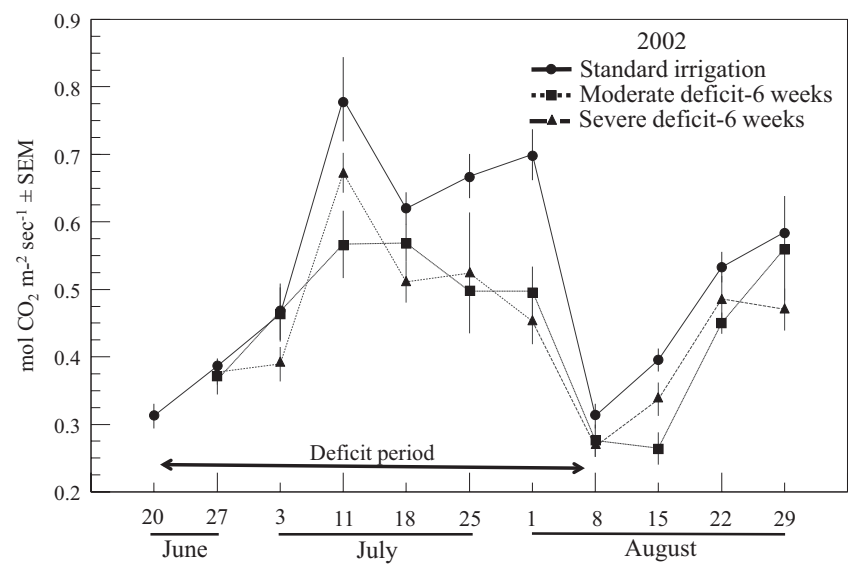

Fig. 2. Stomatal conductance (mean mol $\mathrm{CO}_{2} \mathrm{~m}^{-2} \mathrm{~s}^{-1} \pm \mathrm{SE}$ ) over time, 2002, 6-wk deficit duration.

but no difference between moderate and severe deficit treatments $(F=1.07 ; \mathrm{df}=1,22 ; P=0.31)$, and there was no significant difference in deficit intensity at the 6 -wk duration $(F=3.04 ; \mathrm{df}=2,22 ; P=0.07)$. For the subsequent 4 wk (13 Aug-3 September), there was no significant effect of deficit intensity for $3 \mathrm{wk}$ $(F=0.28 ; \mathrm{df}=1,14 ; P=0.60)$ or 6 -wk duration $(F=$ 3.18; $\mathrm{df}=1,14 ; P=0.09)$.

Leafhopper Nymphal Density. In 2002, we estimated the second generation to have been between primarily between 8 August and 12 September. There was no overall deficit duration effect $(F=3.68$; $\mathrm{df}=$ 1,$172 ; P=0.06$ ), with no interaction between deficit duration and intensity $(F=0.35 ; \mathrm{df}=1,172 ; P=0.55)$ (Figs. 5 and 6). However, there was an overall second generation deficit intensity effect $(F=44.0 ; \mathrm{df}=2$, $211 ; P<0.01$ ), with the deficit treatments $36.3 \%$ lower than the control (contrast: $F=69.7$; df $=1,211 ; P<$ 0.01 ) (Figs. 5 and 6), and the moderate deficit 22.8\% lower than the severe deficit (contrast: $F=18.2$; df $=$ 1,$211 ; P<0.01$ ) (Figs. 5 and 6 ).
In 2003, we estimated the second generation of leafhoppers to have been between 30 July and 3 September, and the third generation between 16 September and 8 October. There was a significant effect of deficit intensity for the second generation $(F=114.13$; $\mathrm{df}=2,216 ; P<0.01$ ), with the deficits $69.6 \%$ lower than the control (contrast: $F=226.07 ; \mathrm{df}=1,216 ; P<$ 0.01 ) but not between the moderate and severe deficit treatments $(F=2.19 ; \mathrm{df}=1,216 ; P=0.14)$. There was no significant overall deficit duration effect for the second generation $(F=0.43 ; \mathrm{df}=1,172 ; P=0.51)$, but there was significant interaction between deficit duration and intensity $(F=14.89 ; \mathrm{df}=1,172 ; P<0.01)$, such that there was no significant difference between the moderate and severe deficit treatments at $3 \mathrm{wk}$ $(F=3.51 ; \mathrm{df}=1,84 ; P=0.06)$ (Fig. 5$)$, but at $6 \mathrm{wk}$ the severe deficit treatment was $44 \%$ lower than the moderate deficit $(F=15.81 ; \mathrm{df}=1,84 ; P<0.01)$ (Fig. 6 ). For the third generation, there was a significant effect of deficit duration, with the 6 -wk treatment $12 \%$ lower than $3 \mathrm{wk}(F=4.12 ; \mathrm{df}=1,172 ; P=0.04)$, but

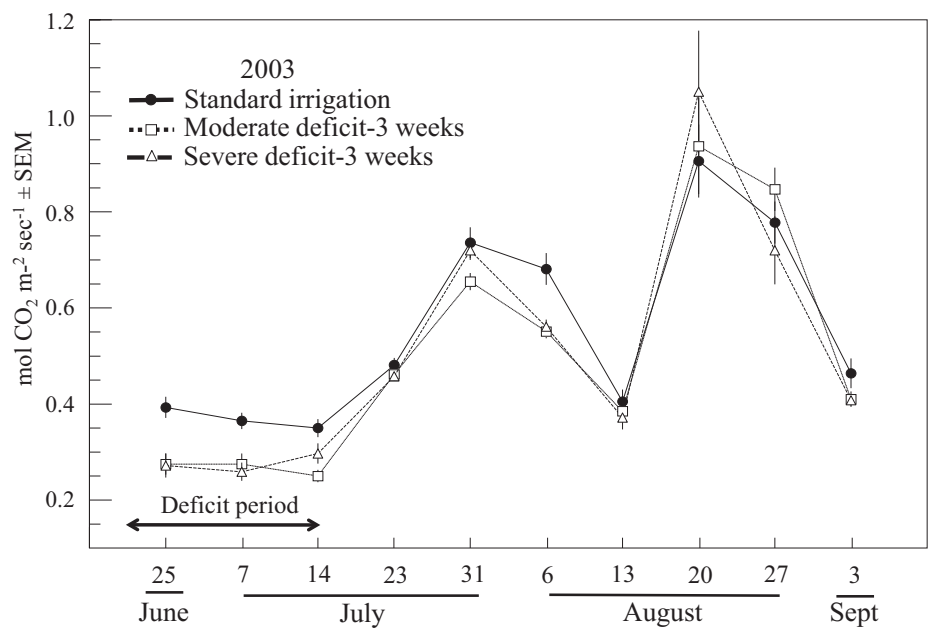

Fig. 3. Stomatal conductance (mean $\mathrm{mol} \mathrm{CO} 2 \mathrm{~m}^{-2} \mathrm{~s}^{-1} \pm \mathrm{SE}$ ) over time, 2003, 3-wk deficit duration. 


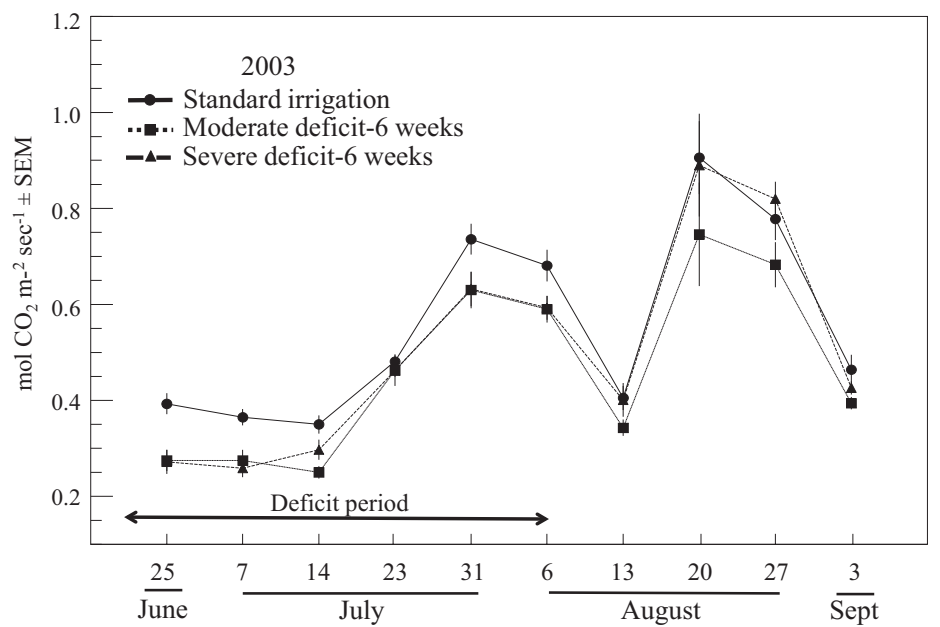

Fig. 4. Stomatal conductance (mean $\mathrm{mol} \mathrm{CO}_{2} \mathrm{~m}^{-2} \mathrm{~s}^{-1} \pm \mathrm{SE}$ ) over time, 2003, 6-wk deficit duration.

no interaction between duration and intensity $(F=$ $1.31 ; \mathrm{df}=1,172 ; P=0.25)$. For the third generation, there was a significant effect of deficit intensity $(F=$ 35.16 ; $\mathrm{df}=2,216 ; P<0.01)$, with the deficits $32.0 \%$ lower than the control (contrast: $F=33.36$; $\mathrm{df}=1,216$; $P<0.01)$ and the severe deficit $41.4 \%$ lower than the moderate deficit $(F=36.95$; $\mathrm{df}=1,216 ; P<0.01)$.

Leafhopper Eggs. For the second generation in 2003, there was a significant effect of deficit intensity, with the deficit treatments $44.4 \%$ lower than control in total eggs $(F=35.2$; df $=2,355 ; P<0.01)$, and $38.7 \%$ lower in hatched eggs $(F=23.1 ; \mathrm{df}=2,355 ; P<0.01)$ (Table 2), but no significant difference between the moderate and severe deficit treatments. There was a significant effect of deficit duration, with the 6 -wk deficit lower than the 3-wk deficit by $60.1 \%$ for total eggs $(F=7.33$; df $=2,232 ; P<0.01)$, with no interaction between duration and intensity $(F=1.20$; $\mathrm{df}=$ $1,232 ; P=0.31)$, and by $69.5 \%$ for hatched eggs $(F=$ 13.50 ; $\mathrm{df}=2,232 ; P<0.01)$, again with no interaction
$(F=2.68 ; \mathrm{df}=1,232 ; P=0.10)$ (Table 2$)$. For the third generation, there was a significant effect of deficit intensity, with the severe deficit $23.6 \%$ lower than the moderate deficit treatment and $28.1 \%$ lower than the control in total eggs $(F=13.74$; $\mathrm{df}=2,355 ; P<0.01)$, and the severe deficit $30.5 \%$ lower than the moderate deficit treatment and $35.2 \%$ lower than the control in hatched eggs $(F=18.17$; df $=2,355 ; P<0.01)$ (Table $2)$. There was no significant difference in duration $(F=1.79 ; \mathrm{df}=1,232 ; P=0.18)$, with no interaction between duration and intensity $(F=1.08$; $\mathrm{df}=2,232$; $P=0.3)$. There was no difference in percentage of parasitism for deficit intensity nor duration for either the second or third generation (Table 2).

\section{Discussion}

Our study confirms the results of others who have found a negative response by cicadellids to plant water stress intensity (Schroeder et al. 1988, Hoffman and

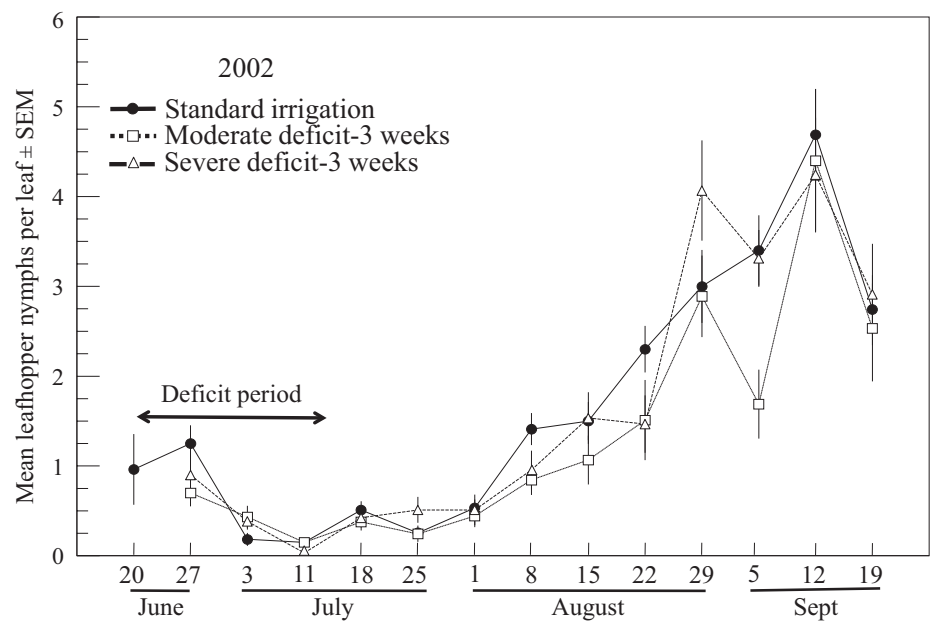

Fig. 5. Leafhopper nymphs per leaf (mean $\pm \mathrm{SE}$ ) over time, 2002, 3-wk deficit duration. 


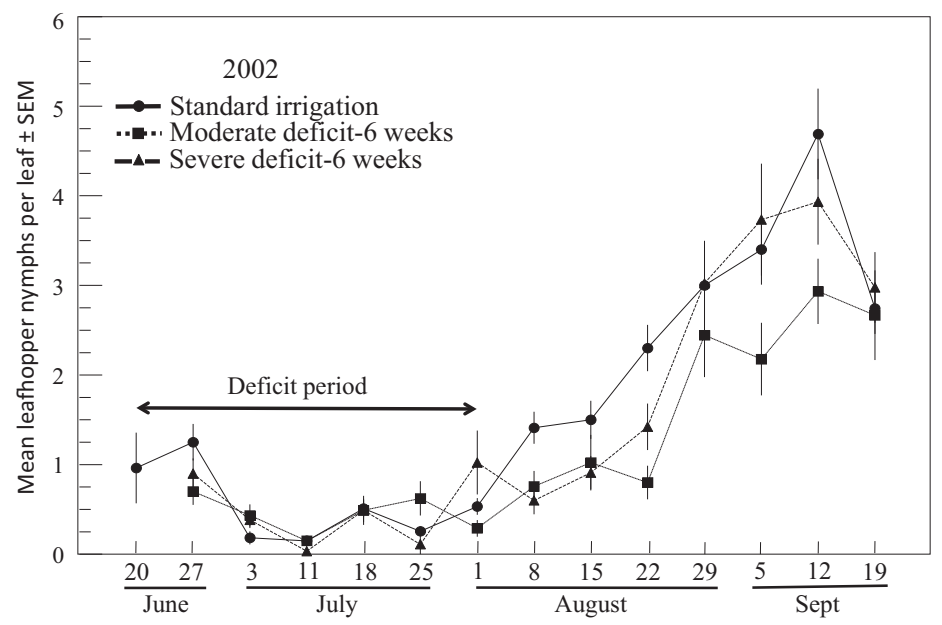

Fig. 6. Leafhopper nymphs per leaf (mean $\pm \mathrm{SE}$ ) over time, 2002, 6-wk deficit duration.

Hogg 1992, Al-Dawood et al. 1996, Nadel et al. 2008, Krugner et al. 2009), and, more specifically, that Erythroneura spp. are negatively affected by water stressed grapevines (Trichilo et al. 1990, Daane and Williams 2003, Costello 2008). Whereas Trichilo et al. (1990) and Daane and Williams (2003) used seasonwide water deficits, the current study found similar results with a much reduced deficit time period, that is, an RDI between berry set and veraison, confirming the work of Costello (2008). Similar to Costello (2008), our study found little difference in leafhopper response between moderate and severe deficit intensities. And, in a variation previously untested on grape, we found little difference between maintaining the deficit for the entire period between veraison and berry set $(6 \mathrm{wk}$ ) versus a shortened deficit time period (3wk).

The overall effect of deficit intensity on second generation nymphs in the current study, approxi-

Table 2. Effect of treatments on leafhopper egg densities and parasitism by Anagrus spp.

\begin{tabular}{|c|c|c|c|}
\hline Generation & $\begin{array}{l}\text { Mean total } \\
\text { eggs/leaf }\end{array}$ & $\begin{array}{c}\text { Mean } \\
\text { hatched } \\
\text { eggs/leaf }\end{array}$ & $\begin{array}{c}\text { Mean } \% \\
\text { parasitism }\end{array}$ \\
\hline \multicolumn{4}{|l|}{ Generation 2} \\
\hline Control & $9.00 \pm 0.62 \mathrm{a}$ & $2.13 \pm 0.17 \mathrm{a}$ & $0.31 \pm 0.03 a$ \\
\hline $\begin{array}{l}\text { Moderate deficit } \\
\quad(50 \% \text { irrigation })\end{array}$ & $4.85 \pm 0.69 b$ & $0.98 \pm 0.19 b$ & $0.28 \pm 0.06 \mathrm{a}$ \\
\hline $\begin{array}{l}\text { Severe deficit } \\
\quad(25 \% \text { irrigation })\end{array}$ & $5.16 \pm 0.91 b$ & $1.63 \pm 0.38 \mathrm{~b}$ & $0.16 \pm 0.05 a$ \\
\hline 3-wk duration & $7.16 \pm 1.04 \mathrm{a}$ & $2.00 \pm 0.39 \mathrm{a}$ & $0.19 \pm 0.04 \mathrm{a}$ \\
\hline 6-wk duration & $2.85 \pm 0.36 b$ & $0.61 \pm 0.14 \mathrm{~b}$ & $0.25 \pm 0.08 \mathrm{a}$ \\
\hline \multicolumn{4}{|l|}{ Generation 3} \\
\hline Control & $13.66 \pm 0.79 a$ & $10.71 \pm 0.64 a$ & $0.14 \pm 0.02 a$ \\
\hline $\begin{array}{l}\text { Moderate deficit } \\
\quad(50 \% \text { irrigation })\end{array}$ & $12.85 \pm 1.01 \mathrm{a}$ & $9.98 \pm 0.76 a$ & $0.10 \pm 0.01 \mathrm{a}$ \\
\hline $\begin{array}{l}\text { Severe deficit } \\
\quad(25 \% \text { irrigation })\end{array}$ & $9.81 \pm 0.86 \mathrm{~b}$ & $6.93 \pm 0.59 b$ & $0.17 \pm 0.03 \mathrm{a}$ \\
\hline 3-wk duration & $11.86 \pm 0.93 \mathrm{a}$ & $8.43 \pm 0.61 \mathrm{a}$ & $0.15 \pm 0.02 \mathrm{a}$ \\
\hline 6-wk duration & $10.80 \pm 0.97 \mathrm{a}$ & $8.48 \pm 0.78 a$ & $0.12 \pm 0.02 \mathrm{a}$ \\
\hline
\end{tabular}

Means followed by the same letter are not significantly different $(P>0.05)$. mately a $38 \%$ reduction in 2002 and a $70 \%$ reduction in 2003 , is in line with leafhopper response to RDI in similar studies: a $52 \%$ reduction at the Aliso vineyard (Firebaugh, San Joaquin Valley), and a 51 and $40 \%$ reduction at the Frankel vineyard (Paso Robles) in 2000 and 2002, respectively (Costello 2008). Our study repeated the deficit intensity comparison (moderate [50\% of full irrigation] versus severe [ $25 \%$ of full irrigation]) made at the Frankel vineyard in 2002 (Costello 2008), but the results were mixed. In the current study, the moderate deficit resulted in approximately a $23 \%$ lower nymphal density compared with the severe deficit in 2002, which is counterintuitive, and there was no difference between deficit intensities in 2003. At the Frankel vineyard in 2002, the severe deficit was $4.5 \%$ lower than the moderate deficit (Costello 2008). In general, there was little overall difference between the two deficit intensities.

The reduction in leafhopper egg density in the current study is consistent with previous findings. Hoffman and Hogg (1992) found that oviposition rate was lowered for potato leafhopper by 28 and $43 \%$ under moderate and severe water deficits, respectively, and Daane and Williams (2003) found that deficits of 0.6 $\mathrm{ET}_{\mathrm{c}}$ and no irrigation resulted in lower E. variabilis egg density by 34.6 and $81.3 \%$, respectively. Costello (2008) found that moderate water stress lowered second generation leafhopper egg density by 54 and 30\% at the Aliso and Frankel (2000) field sites, respectively. The current study's findings on egg density are consistent with the reduction in nymphal density seen under deficit irrigation: there was an overall effect of the deficits on second generation nymphs (Figs. 7 and 8 ), and for third generation nymphs, only the severe deficit was lower than the control (Figs. 7 and 8), which mirrors the pattern of the deficit treatments on egg density (Table 2). The effect of deficit duration corresponded to this only partly: the difference in second generation nymphal density between intensities was only realized with the 6 -wk time period (i.e., intensity by duration interaction), whereas second 


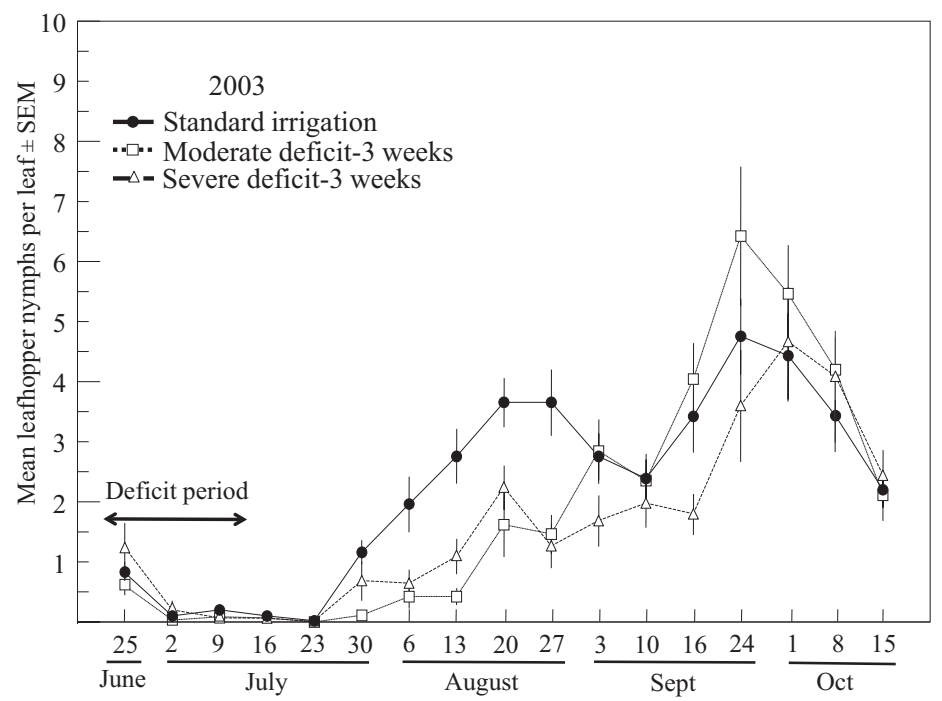

Fig. 7. Leafhopper nymphs per leaf (mean \pm SE) over time, 2003, 3-wk deficit duration.

generation egg density was lower overall at the 6-wk time period compared with $3 \mathrm{wk}$. Both of these pieces of evidence indicate that differences in oviposition rate are a cause for lower nymphal density.

Results also suggest that nymphal mortality played a role in lower nymphal density, because the differences among treatments in peak nymphal density (the moderate deficit was $65.5 \%$ lower and the severe deficit $80.0 \%$ lower than control, respectively) were greater than the differences among treatments in second generation hatched eggs $(53.9 \%$ for the moderate deficit and $23.4 \%$ for the severe deficit). Because parasitism did not differ among treatments, the explanation for the higher rate of nymphal mortality would lay in the water deficits. This was also found by Costello (2008), where at the Aliso and Frankel (2000) vine- yards with a $50 \%$ of full irrigation treatment, the differences were 18 and 30 percentage points, respectively. In the current study, the wider gap between second generation egg and peak nymphal density for the severe deficit (56.6 percentage points) versus the moderate deficit (11.6 percentage points) suggests that the more intense deficit of $25 \%$ of full irrigation contributed greatly to nymphal mortality. Possible reasons for higher nymphal mortality feeding on water stressed leaves include increases in leaf cuticle thickness, and the difficulty in water extraction on leaves with low water potential, each of which would need formal testing.

That the moderate and severe deficit treatments diverged in the effect on third generation nymphal density in 2003 may provide a further clue as to the

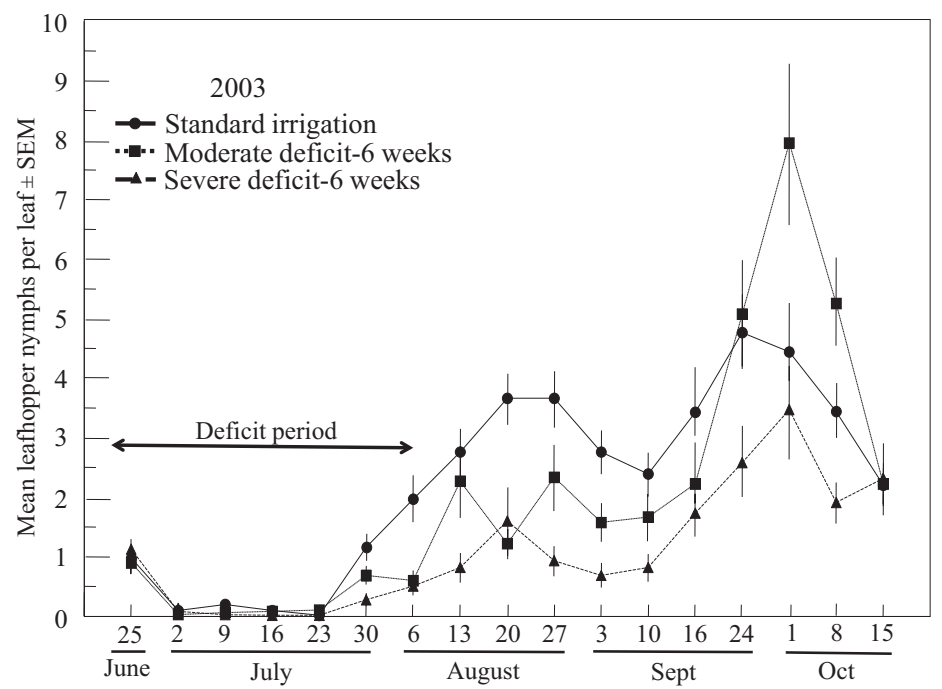

Fig. 8. Leafhopper nymphs per leaf (mean \pm SE) over time, 2003, 6-wk deficit duration. 
mechanism for leafhopper reduction. Regardless of deficit duration, only the severe deficit intensity maintained significantly lower nymphal density compared with the control in the third generation (Figs. 7 and 8). This contrasts with previous results from the Aliso vineyard (Costello 2008), in which a 6 -wk berry setto-veraison moderate deficit resulted in an almost $62 \%$ reduction of leafhopper nymphs in the third generation. What might explain this is that at the Aliso vineyard (Costello 2008), the 6-wk RDI 50\% of full irrigation was followed by $80 \%$ of full irrigation for the remainder of the season, whereas in the current study the postdeficit irrigation intensity was returned to full irrigation. We suggest that the difference in how the leafhoppers responded to these two approaches may have been due to the amount of new shoot growth that the vines put on. Although not measured, it is possible that vines rewatered at full irrigation had an accelerated vegetative growth rate relative to the control vines. Cui et al. (2009) suggested that pear-jujube, Zizyphus jujube Mill., subjected to severe deficit was not able to recover after rewatering, but rewatering after a period of moderate deficit (50\% of full irrigation) increased photosynthetic activity and water use efficiency and indicated that this may stimulate nutrient accumulation and vegetative activity. Whereas in the current study, stomatal conductance results do not indicate that the severe deficit had an irreversible effect on photosynthesis (Figs. 1-4), the pattern of egg density (Table 2 ), and subsequently nymphal density (Figs. 7 and 8), suggests that the severe deficit treatment had a lasting effect on the grape vines. More new shoot growth would translate into more plant material of the suitable age or quality for oviposition and may lead to better nymphal survival.

That there was little difference in the effect of deficit duration on nymphal density also supports the idea that oviposition, and subsequently nymphal density, is related to the availability of new shoot growth. In 2002, there was no significant difference in nymphal density with a 3- or 6-wk deficit duration (Figs. 5 and $6)$. In 2003 , the reductive effect on second generation nymphs was with the combination of the six week time period and the more intense deficit of $25 \%$ of full irrigation (Fig. 8), i.e., intensity by duration interaction; a slightly reduced number of third generation nymphs was realized with the 6 -wk deficit duration in general. What this suggests is that a time period of just $3 \mathrm{wk}$ postberry set is sufficient to curtail new shoot growth, or for gravid female leafhoppers to sense a degree of water stress in the vines. If this water stress corresponds to the main period of oviposition, it will have an effect on leafhopper density for the rest of the generation, even if the vines recover from the deficit treatments before the generation is completed.

Given these results, there are possible RDI management strategies to prevent second generation leafhopper nymphal density from rising above economic thresholds and to maintained this through the third generation. One would be to follow the 25 or $50 \%$ RDI between berry set and veraison, and follow with irrigation at $<1.0 \mathrm{ET}_{\mathrm{c}}$ thereafter. How much less is not certain, but results from the Aliso vineyard (Costello 2008) show that $0.80 \mathrm{ET}_{\mathrm{c}}$ was effective in achieving this. Another possibility is that, after the original RDI duration ends, irrigation could be increased to $1.0 \mathrm{ET}_{\mathrm{c}}$, but then the deficit reinstated to correspond to the third leafhopper generation. Results suggest that this could be done with a deficit duration as short as $3 \mathrm{wk}$. Such decisions would have to made in the context of acceptable yield loss, as in the current study overall yield was reduced by $\approx 24 \%$ under RDI, with no yield difference between deficit intensities and no effect of deficit duration (Costello and Patterson 2012).

\section{References Cited}

Al-Dawood, A. S., E. B. Radcliffe, E. A. Backus, and W. L. Koukkari. 1996. Probing behavior of potato leafhopper (Homoptera: Cicadellidae) on alfalfa influenced by plant water deficit. J. Econ. Entomol. 89: 898-905.

Acevedo-Opazo, C., S. Ortega-Farias, and S. Fuentes. 2010. Effects of grapevine (Vitis vinifera L.) water status on water consumption, vegetative growth and grape quality: an irrigation scheduling application to achieve regulated deficit irrigation. Agric. Water Manage. 97: 956-964.

California Department of Pesticide Regulation. 2004. Summary of pesticide use report data, 2003, indexed by commodity. Department of Pesticide Regulation, California Environmental Protection Agency, Sacramento, CA.

Chalmers, D. J., G. Burge, P. H. Jerie, and P. D. Mitchell. 1986. The mechanism of regulation of Bartlett pear fruit and vegetative growth by irrigation withholding and regulated deficit irrigation. J. Am. Soc. Hortic. Sci. 111: $904-$ 907.

Chaves, M. M., T. P. Santos, C. R. Souza, M. F. Ortuño, M. L. Rodrigues, C. M. Lopes, J. P. Maroco, and J. S. Pereira. 2007. Deficit irrigation in grapevine improves water-use efficiency while controlling vigour and production quality. Ann. Appl. Biol. 150: 237-252.

Costello, M. J. 2008. Regulated deficit irrigation and density of Erythroneura spp. (Hemiptera: Cicadellidae) on grape. J. Econ. Entomol. 101: 1287-1294.

Costello, M. J., and W. K. Patterson. 2012. Regulated deficit irrigation effect on yield and wine color of Cabernet Sauvignon in Central California. HortScience (in press).

Cui, N., T. Du, F. Li, L. Tong, S. Kang, M. Wang, X. Liu, and Z. Li. 2009. Response of vegetative growth and fruit development to regulated deficit irrigation at different growth stages of pear-jujube tree. Agric. Water Manage. 96: 1237-1246.

Daane, K. M., and L. E. Williams. 2003. Manipulating vineyard irrigation amounts to reduce insect pest damage. Ecol. Appl. 13: 1650-1666.

Dantas, B. F., M.A.C. de Lima, C. R. Souza, L. H. Bassoi, L. Ribeiro de Sa, S. R. Luz de Sousa, and J.M.P. de Lima Filho. 2007. Foliar carbohydrate content and invertase activity of 'Syrah' and 'Moscato Canelli' vines subjected to partial rootzone drying and regulated deficit irrigation. Acta Hortic. 754: 301-307.

dos Santos, T. P., C. M. Lopes, M. L. Rodrigues, C. R. de Souza, J. M. Ricardo-da-Silva, J. P. Maroco, J. S. Pereira, and M. M. Chavesdos. 2007. Effects of deficit irrigation strategies on cluster microclimate for improving fruit composition of Moscatel field-grown grapevines. Sci. Hortic. 112: 321-330.

Fornasiero, D., C. Duso, A. Pozzebon, D. Tomasi, F. Gaiotti, and F. Pavan. 2012. Effects of irrigation on the seasonal 
abundance of Empoasca vitis in north-Italian vineyards. J. Econ. Entomol. 105: 176-185.

Hoffman, G. D., and D. B. Hogg. 1992. Effect of alfalfa water stress on potato leafhopper (Homoptera: Cicadellidae) plant preference and oviposition rate. Ann. Entomol. Soc. Am. 85: 506-516.

Hunter, W. B., and E. A. Backus. 1989. Mesophyll-feeding by the potato leafhopper, Empoasca fabae (Homoptera: Cicadellidae): results from electronic monitoring and thin-layer chromatography. Environ. Entomol. 18: 465472 .

Krugner, R., J. R. Hagler, J. G. Morse, A. P. Flores, R. L. Groves, and M. W. Johnson. 2009. Seasonal population dynamics of Homalodisca vitripennis (Hemiptera: Cicadellidae) in sweet orange trees maintained under continuous deficit irrigation. J. Econ. Entomol. 102: 960-973.

Nadel, H., R. Seligmann, M. W. Johnson, J. R. Hagler, D. C. Stenger, and R. L. Groves. 2008. Effects of citrus and avocado irrigation and nitrogen-form soil amendment on host selection by adult Homalodisca vitripennis (Hemiptera: Cicadellidae). Environ. Entomol. 37: 787795 .

Prichard, T., B. Hanson, L. Schwankl, P. Verdegaal, and R. Smith. 2004. Deficit irrigation of quality winegrapes us- ing micro-irrigation techniques. University of California Cooperative Extension, Department of Land, Air and Water Resources, University of California-Davis, Davis, CA.

Santesteban, L. G., C. Miranda, and J. B. Royo. 2011. Regulated deficit irrigation effects on growth, yield, grape quality and individual anthocyanin composition in Vitis vinifera L. cv. 'Tempranillo.' Agric. Water Manage. 98: 1171-1179.

SAS Institute. 2010. SAS/STAT user's guide, release 9.3 ed. SAS Institute, Cary, NC.

Schroeder, P. C., R. L. Brandenburg, and C. J. Nelson. 1988. Interaction between moisture stress and potato leafhopper Homoptera: Cicadellidae) damage in alfalfa. J. Econ. Entomol. 81: 927-933.

Trichilo, P. J., L. T. Wilson, and D. W. Grimes. 1990. Influence of irrigation management on the abundance of leafhoppers (Homoptera: Cicadellidae) on grapes. Environ. Entomol. 19: 1803-1809.

Williams, L. E., C. J. Phene, D. W. Grimes, and T. J. Trout. 2003. Water use of mature Thompson Seedless grapevines in California. Irrigat. Sci. 22: 11-18.

Received 21 September 2011; accepted 12 April 2012. 